\title{
Bireysel Banka Müşterilerinin Online Bankacılığa Yönelik Tutum ve Davranışlarının İncelenmesi
}

\author{
Mine Berber $^{a, b}$, Aslihan Nakiboğlu ${ }^{c}$
}

\section{Özet}

$\mathrm{Bu}$ araştırma bireysel banka müşterilerinin online bankacıllğa yönelik tutum ve davranışlarını incelemek amacıyla gerçekleştirilmiştir. Amaç doğrultusunda hazırlanan anket formu, Niğde Ömer Halisdemir Üniversitesi Etik Kurul'unun 10/12/2020 tarih ve 7227 sayılı onayı ile 12-31 Aralık 2020 tarihleri arasında online olarak uygulanmıştır. Ulaşılan veriler SPSS 22.0 istatistik programında analiz edilmiştir. Katılımcıların tanımlayıcı özelliklerini belirlenmesinde frekans ve yüzde analizlerinden, online bankacılığa yönelik tutum ve davranışlarının incelenmesinde ortalama ve standart sapma analizlerinden faydalanılmıştır. Katılımcıların tanımlayıcı özelliklerine göre online bankacıllğa yönelik tutum ve davranışlarının incelenmesinde ise $t$ testi, tek yönlü Anova testi ve Anova sonrası farklılık bulunan grupların kaynağını incelemede post-hoc analizlerine başvurulmuştur. Araştırma sonucunda bireysel banka müşterilerinin online bankacılığa yönelik oldukça olumlu tutumlar içerisinde oldukları, katılımcıların cinsiyetlerine ve online bankacılıkta en çok yaptıkları işlemlere göre online bankacılığa yönelik tutum ve davranışlarında farklılıkların olmadığı, yaşlarına, medeni durumlarına, öğrenim durumlarına ve online bankacılık kullanım sıklıklıklarına göre, farklılaşmaların olduğu belirlenmiştir.

\section{Examination of Attitudes and Behaviors of Individual Bank Customers Related to Online Banking}

\begin{abstract}
This research was conducted to examine the attitudes and behaviors of individual bank customers towards online banking. The questionnaire prepared for the purpose was applied online between 12-31 December 2020 with the approval of the Ethics Board of Niğde Ömer Halisdemir University on 10/2/2020 and 7227. The data obtained were analyzed in SPSS 22.0 statistical program. Frequency and percentage analyses were used to determine the descriptive characteristics of the participants, and mean and standard deviation analyses were used to examine their attitudes and behaviors towards online banking. In the study of the attitudes and behaviors of participants towards online banking according to their descriptive characteristics, post-hoc analyses were applied to examine the source of the groups with differences after the T-test, one-way ANOVA test and Anova. Individual bank customers towards online banking as a result of research that were quite positive attitudes of the participants towards online banking to do most of what gender and the absence of differences in attitude and behavior compared to their age, their marital status, educational status, and according to frequent use online banking, it was determined that differentiation.
\end{abstract}

\author{
Anahtar Kelimeler \\ Online Bankacılık \\ Bireysel Banka Müşterileri \\ İnternet Bankacılığ \\ Bankacılık İşlemleri \\ Makale Hakkında \\ Geliş Tarihi: 02.02.2021 \\ Kabul Tarihi: 24.09.2021 \\ Doi: 10.18026/cbayarsos.873169
}

\footnotetext{
a İletişim Yazarı: mineberber51@gmail.com

b İktisat Bilim Uzmanı, Niğde Ömer Halisdemir Üniversitesi / İktisadi ve İdari Bilimler Fakültesi İktisat 0000-0001-5497-9523

c Doç.Dr. Niğde Ömer Halisdemir Üniversitesi /İktisadi ve İdari Bilimler Fakültesi İktisat 0000-0002-6825-984X
} 


\section{Giriş}

İçinde bulunduğumuz yüzyılda yaşanan bilgi ve iletişim teknolojileri alanında yaşanan gelişim ve değişimler sosyal ve ekonomik yaşamın tüm alanlarını etkilemiş, bu etkiler bazı sektörlerde daha yoğun olarak hissedilmiştir. Bu sektörlerden birisi de bankacılıktır. Özellikle bireysel banka müşterilerinin sosyal hayatlarında ihtiyaç duydukları fatura ödeme, kredikredi kartı işlemleri ve para transferi yapma gibi işlemler bankacılık sektöründe yaşanan gelişmeler sayesinde daha kolay banka şubesine gitmeden yapılabilir hale gelmiştir. Bireysel bankacılık işlemleri ilk önce ATM'ler aracılığıyla yapılmaya başlanmış, ilerleyen yıllarda internet teknolojileri sayesinde önce bilgisayarlara ardından ise akıllı telefonlar sayesinde bireylerin ceplerine kadar gelerek zamandan ve mekandan bağımsız ve kolay bir şekilde online olarak yapılmaya başlanmıştır.

Basın yayın organlarında çıkan online bankacılık şifrelerinin çalınması, kredi kartı bilgilerinin kopyalanması gibi haberler bireylerin online bankacılığa yönelik tutum ve davranışları üzerinde olumsuz etkiler bıraksa da, bankaların her geçen gün artırdığı güvenlik tedbirlerinin yanısıra, hukuksal açıdan online bankacılık yoluyla çalınan paralardan bankaların sorumlu tutulmasına yönelik kararların alınması (Vatan Gazetesi, 25 Eylül 2019) kullanım kolaylığı ve sunduğu avantajlardan dolayı online bankacılığa yönelik ilginin giderek arttığ1 gözlenmektedir. Online bankacılığa yönelik güven unsurunun arttırılması kapsamında Bankacılık Düzenleme ve Denetleme Kurumu'nun 15 Mart 2020 tarihli “Bankaların Bilgi Sistemleri ve Elektronik Bankacılık Hizmetleri Hakkındaki Yönetmelik'te önemli gelişmeler içermektedir. Adı geçen yönetmeliğin 35. maddesinde;

"Banka, akıllı telefonlar gibi birden fazla kimlik doğrulama bileşeninin bankaya iletilmesinde kullanılan mobil cihazlar üzerindeki bankacılık uygulamalarının kullandığı hassas verilerin, aynı mobil cihaz üzerindeki diğer uygulamalar ve çalışmakta olan işlemler tarafından erişilemez olmasını sağlayacak önlemler alır. Banka, söz konusu mobil cihazların kaybolması ya da çalınması halinde bunlar üzerindeki hassas verilerin yetkisiz kişilerce erişilemez olmasını sağlamak ve mobil cihazların ele geçirilmesi, güvenilirliğinin bozulması, işletim sistemi yazılımının kırılması veya değiştirilmesi gibi hallerden kaynaklanacak risklerin azaltılması amaciyla günün teknolojisine uygun kontroller tesis etmekle yükümlüdür." ifadesi yer almaktadir.

Böylelikle online bankacılık işlemleri sırasında herhangi bir güvenlik açı̆̆ından bankalar sorumlu tutularak, tüketicilerin online bankacılığa yönelik işlemlerindeki güvenlik kaygıları giderilmeye çalışılmıştır.

Literatürde online bankacılığa yönelik tutum ve davranışları inceleyen çalışmalar mevcuttur (Okumuş, Bozbay ve Dağlı, 2010; Altınöz, 2016; Özkan ve İpekten, 2017; Kaplan, 2019; Kocabıyık ve Fattah, 2019). Ancak içinde bulunulan Covid-19 salgın dönemi, diğer dönemlerden farklı özellikler içermektedir. Salgın nedeniyle uygulanan önlemler, dışarı çıkma kısıtlamaları vb. uygulamalar, bireyleri daha fazla elektronik ticarete yöneltmiş, bu durumun da online bankacılığa yönelik tutum ve davranışları etkilediği düşünülmüştür.

$\mathrm{Bu}$ çalışmada bireysel banka müşterilerinin online bankacılığa yönelik tutum ve davranışları Niğde ili özelinde incelenmektedir. Bu kapsamda araştırmada öncelikle online bankacılık tanımlanmakta, online bankacılık tercihinde etkili olan faktörlerden bahsedilmektedir. Araştırmanın uygulama kısmında yönteminden bahsedilerek, elde edilen veriler tablo ve grafikler aracılığıyla yorumlanarak sunulmaktadır. 


\section{Online Bankacılik}

Günümüzde her alanda çok hızlı bir değişim ve gelişim yaşanmaktadır. Bu değişim ve gelişimin tetikleyici unsuru olarak iletişim ve iletişim teknolojilerinin etkileri yaşamın her alanında kendini hissettirmektedir. İletişimin bu denli gelişiminde internet kullanımının yaygınlaşmasının önemli bir yeri bulunmaktadır. Sosyal ve ekonomik yaşamın hemen hemen her alanında kullanımı yaygınlaşan internet, zaman ve mekândan bağımsız kullanımı ve karşılıklı etkileşime olanak sağladığından bireylerin yaşamının adeta vazgeçilmezi haline gelmiştir (Kaplan, 2019, s. 126). Gelişen bu teknoloji ve hızlı değişimler neticesinde insanlar artık günlük ihtiyaçlarının karşılanmasında bile internetten e-ticaret uygulamalarıyla faydalanmakta ve bu durum internet kullanımını daha popüler bir hale getirmektedir (Titu ve Rahman, 2013, s. 37).

Teknolojik alanda yaşanan değişim ve gelişimler tüm sektörleri bir şekilde etkisi altına almaktadır. Yaşanan bu değişim ve gelişimden yoğun etkilenen sektörlerden birisi de bankacılıktır. Her geçen gün pazar payı büyüyen bankacılık sektöründe yoğun bir rekabet yaşanmaktadır. Bu rekabet ortamı bankacılığın gelişimine olumlu katkı sağlayarak değişimin ve gelişimin hızını artırmaktadır (Kaya ve Arslan, 2016, s. 424; Yılmaz, Boz ve Yaprak, 2017, s. 1703). Rekabete ön planda olmak için müşterilerin memnun edilmesi, istek ve beklentilerinin hızlı bir şekilde giderilmesi önem kazanmaktadır. Müşteri istek ve beklentilerinin hızlı bir şekilde karşılanmasında internet bankalara önemli avantajlar sağlamaktadır (Okumuş, Bozbay ve Dağlı, 2010, s. 90). Bankacılık sektörüne teknolojinin girmesi, müşterilerin bankacilık hizmetlerinden her zaman ve her yerde ATM, İnternet Bankacilığı ve online bankacılık şeklinde yararlanmasını sağlamıştır (Solanki, 2018, s. 978).

Online bankacılık; bankacılık işlemlerinde iletişimin internet ortamında gerçekleştirilmesini ifade etmektedir (Kaya ve Arslan, 2016, s.425). Online bankacılık, bankaların müşterilerinin bilgi almak için talep edebilecekleri ve bankacılık işlemlerinin çoğunu akıllı cihazları ve bilgisayarları aracılığıyla gerçekleştirebilecekleri çeşitli hizmetler sunmaktadır (Suriya, Mahalakshmi ve Karthik, 2012, s. 15). Online bankacılık internete bağlanan bir cihaz (bilgisayar, akıllı telefon, tablet, vb) ile zaman ve mekandan bağımsız olarak internet üzerinden bankacılık hizmetlerinin verildiği alternatif bir dağıtım kanalıdır. Dünyanın her yerinden 7/24 internet erişimi olan bir cihazdan kullanılabilen bir hizmettir (Özkan ve İpekten, 2017, s. 649). Diğer bir ifade ile online bankacılık, bankaların ve müşterilerin fiziksel kaynaklarını kullanmadan teknoloji yoluyla bankacılık hizmetleri sunma süreci olarak ifade edilmektedir. Bu tanım, internet bankacıllı̆ının daha az banka ve müşteri kaynağı kullandığını göstermektedir. Online bankacılık sayesinde, bankalar tarafından fatura sunumu, fon transferi, yatırım alımları ve satışları, kredi işlemleri, banka ekstrelerini kontrol etme ve diğer birçok hizmet gibi internet medyası aracılığıyla geniş bir hizmet yelpazesi sunulmaktadır (Alsajja ve Dennis 2010, s. 957).

Online bankacılık son yıllarda farklı kitleler tarafından kabul görerek kullanımı artmıştır. Özellikle internetin farklı özelliklerdeki kitleler tarafından benimsenerek kullanımının artması bireysel bankacılığa yönelen bankalar açısından online bankacılığı önemli bir kanal haline getirmiştir (Okumuş, Bozbay ve Dağlı, 2010, s.91-92). Online bankacıllk, geleneksel bankacılığa hem fırsat hem de rekabet ortamı sağlamıştır. Hızla büyüyen bir dünyada, online bankacılık uygulamaları adeta bir zorunluluk halini almıştır (Titu ve Rahman, 2013, s. 37). 
Online bankacılığın gelişmesinde ve yayılmasında temel iki neden olduğu belirtilmektedir (Pikkarainen vd., 2004, s.1):

a. Birincisi bankalar online bankacılık hizmetleri sayesinde önemli bir maliyet avantaj1 sağlamaktadırlar. Online bankacılık sayesinde bankalar, uygun bir maliyetler ürünlerinin tanıtımını yapabilmekte, hizmetlerini sunabilmektedir. Bu durum önemli düzeyde çalışan işgücünden tasarruf sağlamıştır.

b. İkincisi ise müşterilere sağladığ zaman tasarrufu, hız ve maliyet avantajıdır. Bankacılık hizmetleri için banka şubelerine gitmek zorunluluğunu bulunmayan müşteriler önemli bir zaman avantajı kazanırlarken, 7/24 bankacılık hizmetlerini kendilerinin özgür bir şekilde gerçekleştirmesi hız kazandırmakta, geleneksel bankacılıkta ödedikleri hizmet maliyetlerinin online bankacılıkta düşük olması da maliyet avantajı sağlamaktadır.

Online bankacılık, bankacılık operatörleri tarafından uzun yıllardır geliştirilen, gerçek zamanlı, hızlı ve rahat hizmetler sunan bir finansal hizmettir. Tüketiciler, kendilerine ait bir dizi hesap ve şifre için başvurduktan sonra çevrimiçi transferler, faturaların ödenmesi, döviz bozdurma hizmetleri, hesap verilerinin sorgulanması ve finansal yatırımlar gibi çeşitli bankacilık hizmetlerine erişebilirler. Online bankacılık sayesinde tüketiciler, tezgah üstü hizmet için gereken bekleme süresini önemli ölçüde kısaltabilmekte ve bankanın mesai saatleri sinırlamalarından kurtulabilmektedir (Li, Wang ve Hung, 2020).

Online bankacıllk kapsamında bankaların müşterilerine verdikleri hizmetler şu şekilde sıralanabilmektedir (Öztan ve İpekten, 2017, s.649-650):
a. "Hesap Açlışları (vadeli, vadesiz, yatırım,vb.)
b. Para Transferleri (havale, EFT, otomatik havale talimatları)
c. Yatırım İşlemleri (repo, yatırım fonu, hisse senedi, döviz, hazine bonosu gibi menkul
d. Kıymetlerin alımı ve satımı)
e. Ödeme İşlemleri (fatura, vergi, trafik, üniversite harç,vb. ödemeler)
f. Kredi Kartı İşlemleri (her türlü kredi kartı borç ödemeleri)
g. Başvuru İşlemleri (hesap açma, kredi kartı istemi, otomatik ödeme talimatı verme,vb.)”

Görüldügü üzere online bankacılık sayesinde özellikle bireysel banka müşterilerinin banka şubelerinde yapabilecekleri işlemlerin hemen hemen hepsi yapılabilmektedir.

\section{Online Bankacılık Tercihini Etkileyen Faktörler}

Online bankacılık tercihine etki eden faktörlerin bilinmesi ve bu doğrultuda bankaların hizmetlerini geliştirmelerinin ve hizmetlerini çeşitlendirmelerinin online bankacılık kullanıcı sayısının artmasını sağlayacaktır (Uzundağ, 2013, s.50).

Bireylerin online bankacılığa yönelik tutum ve davranışlarında, teknoloji kabul ve bilgi düzeylerinin yanında farklı sosyo psikolojik etkenler ve risk algısı vb. farklı birçok birbirinin içine geçmiş yapılardan etkilendiği belirtilmektedir. Bu nedenle online bankacılık kullanana bireylerin online bankacılığa yönelik tutum ve davranışlarının nasıl olduğu ve online bankacilık kullanmanın avantaj ve dezavantajlarının neler olduğunu bilmek önem arzetmektedir (Doğan, Şen ve Yılmaz, 2015, s. 3-4). 
Bireylerin online bankacılık tercihini etkileyen faktörleri aşağıdaki başlıklar altında inceleyebiliriz;

Kesintisiz ulaşılabilir: Online bankacılı̆̆ının en önemli tercih edilme sebeplerinden birisi, kesintisiz olarak ulaşılmasıdır. Online bankacılık kullanımının müşterileri akıllı cihazları ve bilgisayarlarını birer banka şubesine çevrilebilmektedir. 7/24 saat ulaşılabilirlik, müşterilerin internet kullanımındaki en önemli nedenlerden biridir (Altunöz, 2016, s.133-134).

Yer ve zaman sınırının olmaması: Web tabanlı hizmetlerin sağladığı en önemli avantajlardan birisi zaman ve mekandan bağımsız olmasıdır. Zamandan önemli düzeyde tasarruf sağladığı için online bankacılığın kullanımı hergeçen gün daha da yaygınlaşmaktadır (Kaya ve Arslan, 2016, s. 431). Müşteriler şubeye veya ATM'ye gitmeden işlemlerini online bankacılık ile hızlı bir şekilde yapabilmeleri, zaman ve para tasarrufu sağlamaktadır. Tüm bankalar için, online bankacılık, giderek daha rekabetçi bir bankacılık ortamında pahalı kâğıt işleme ve manuel vezne etkileşimlerini ortadan kaldırmaya yardımcı olurken, yeni müşteriler kazanmak için de güçlü bir araç haline gelmektedir (Titu ve Rahman, 2013, s. 37-38).

Düşük maliyet: Online bankacılık, bankalar için potansiyel bir rekabet avantajı sunmaktadır; bu avantaj, maliyet düşürme ve müşteri ihtiyaçlarının daha fazla karşılanmasıdır (Al-Weshah, 2013, s. 3). Online bankacılıkta özel müşteri, genel müşteri ayrımı yoktur. Masraflar şubelere göre çok daha düşüktür (Altunöz, 2016, s.133-134). Bankacılar, online bankacıllğ 1 işlem maliyetini düşürebilecek, müşteri hizmetlerini geliştirebilecek, müşteri tabanını artırabilecek ve çapraz satış fırsatlarını artırabilecek stratejik bir fırsat olarak görmektedirler (Al-Weshah, 2013, s. 3).

Yalın ve anlaşılır olması: Online bankacılık hizmetlerinin yalın ve anlaşılabilir olması müşteri tercihlerinde etkilidir. Bu konuda bankalar son ylllarda mobil uygulamalarla önemli mesafe katetmişlerdir. Önceden daha zor ve karmaşık olan bankacılık işlemleri hergeçen gün daha anlaşılabilir şekilde sadeleştirilerek, kullanım kolaylığı sunacak şekilde güncellenmektedir. Birçok bankanın mobil asistan kullanarak müşterilerin işlemlerini daha kolay ve hılı bir şekilde gerçekleştirmesine yardımcı olmaya çalıştıkları gözlenmektedir.

Güvenirlik: Bireylerin online bankacılığı tercih etmeleri için, aldıkları hizmetlerin güvenilir olduğuna inanmaları gerekmektedir (Kaya ve Arslan, 2016. 431).bireylerin bankalardan yasal mesajlar geldiğinden emin olmaları ve online bankacılık işlemlerinden üçüncü şahısların haberdar olmamaları gerekmektedir. Özellikle kart bilgi ve şifrelerinin çalışması, bireysel bilgilerin üçüncü şahıslarla paylaşılması konularında bankaların güvenlik sistemlerinin gelişmiş olması gerekliliktir (Barışık ve Temel, 2007:136-160).

\section{Yöntem}

Nicel araştırma yöntemlerine göre hazırlanan araştırmanın bu bölümünde modelinden bahsedilmekte, evren ve örneklemi açıklanarak veri toplama araçları hakkında bilgiler verilerek verilerin analizi açıklanmaktadır.

\section{Araştırma Modeli}

Araştırma genel tarama modelinde gerçekleştirilmiştir. "Genel tarama modelleri, çok sayıda elemandan oluşan bu evrende, evren hakkında genel bir yargıya varmak amacı ile, evrenin 
tümü ya da ondan alınacak bir grup, örnek ya da örneklem üzerinden yapılan tarama düzenlemeleridir" (Karasar, 2012, s.77). Bu çalışmada bireysel banka müşterilerinin online bankacılığa yönelik tutum ve davranışları hakkında Niğde ili özelinde genel bir yargıya ulaşmak için genel tarama modeli seçilmiştir.

\section{Evren ve Örneklem}

Araştırmanın evrenini Niğde ilindeki bireysel banka müşterileri oluşturmaktadır. Niğde ilindeki bireysel banka müşterilerinin tam saysına ulaşılamadığı için Niğde il nüfusundan hareket edilerek Niğde' de yaşayan 18 yaş üzerindeki bireyler evren olarak ele alınmıştır. Buna göre 2019 yılında Niğde'de 18 yaş üzerinde 275.285 kişi yaşamaktadır (https://www.nufusu.com). Tamamının potansiyel bireysel bankacılık müşterisiolma durumu gözönüne alındığında tahmini örnekleme büyüklügü tablosuna göre 100.000 ile 500.000 arasında yer alan evrenler için \%95 güven aralığında ve \%5 hata düzeyinde 383-384 kişilik örneklem büyüklügünün yeterli olacağ1 belirtilmektedir (Büyüköztürk vd., 2016). Bu kapsamda araştırmada belirtilen örneklem büyüklügünün üzerine çıkılmaya çalışılmış ve 394 bireysel banka müşterisine ulaşılmıştır.

\section{Veri Toplama Araçları}

Araştırma verileri bireysel banka müşterilerine yönelik hazırlanan online anket formu ile toplanmıştır. Anket iki bölümden oluşmaktadır. Anketin birinci bölümünde araştırmacı tarafından oluşturulan çoktan seçmeli altı adet çoktan seçmeli soru yer almaktadır. İkinci bölümünde ise Abrol (2014) tarafından geliştirilen ve (Kocabıyık ve Fattah, 2019) tarafından Türkçeye uyarlama çalışması yapılan "Elektronik Bankacılık Tutum Ölçeği” bulunmaktadır. Ölçekte yedi boyut altında 56 tane beşli likert tipinde önerme yeralmaktadır. Araştırmada ölçeğin mevcut faktör yapısı kullanılmıştır, ancak güvenirlik analizleri tekrar edilmiştir. Tablo 1'de ölçekte yer alan boyutlar, içerdikleri önerme sayıları ve güvenirlik analizi sonuçları yer almaktadır.

Tablo 1. Ölçekte Yer Alan Boyut Ve Önermelerin Güvenirlik Değerleri

\begin{tabular}{llll}
\hline Boyut & $\begin{array}{l}\text { Önerme } \\
\text { sayısı }\end{array}$ & $\begin{array}{l}\text { Güvenirlik değeri } \\
\text { (Kocabıyık ve Fattah, 2019) }\end{array}$ & Güvenirlik değeri \\
\hline Güven & 11 & $, 927,11$ &, 958 \\
Sadakat/Bağlılık & 4 & $, 606,4$ &, 778 \\
Hizmet Kalitesi & 13 & $, 914,13$ &, 965 \\
Kullanım Kolaylığı & 5 & $, 825,5$ &, 872 \\
Algılanan Fayda & 6 & $, 913,6$ &, 954 \\
Davranışsal Niyet & 4 & $, 811,4$ &, 936 \\
Müşteri Memnuniyeti & 13 & $, 917,13$ &, 985 \\
Toplam Ölçek Güvenirliği & 56 &, 971 &, \\
\hline
\end{tabular}


Tablo 1'deki veriler incelendiğinde ölçek banka müşterilerinin online bankacılığa yönelik tutum ve davranışlarının incelenmesinde oldukça güvenilir düzeydedir.

\section{Verilerin Toplanması ve Analizi}

Verilerin toplanması için öncelikle Niğde Ömer Halisdemir Üniversitesi Etik Kurul'una başvuruda bulunulmuş ve 10/12/2020 tarih ve 7227 sayılı kararı etik kurul onayı alınmıştır. Online olarak hazırlanan anket formu, bireysel banka müşterilerine, bankalar aracılığı ile akıllı telefonlar vasıtasıyla ulaştırılmıştır. Uygulama 12-31 Aralık 2020 tarihleri arasında gerçekleştirilmiştir.

Ulaşılan veriler SPSS 22.0 istatistik programına aktarılarak analiz edilmiştir. Katılımcıların tanımlayıcı özelliklerinin belirlenmesinde frekans ve yüzde analizlerinden, online bankacılığa yönelik tutum ve davranışlarının incelenmesinde ortalama ve standart sapma analizlerinden faydalanılmıştır. Katılımcıların tanımlayıcı özelliklerine göre online bankacılığa yönelik tutum ve davranışları incelemeden önce verilere normallik testi yapılmış ve verilerin normal dağılım gösterdiği belirlenmiştir. Bu kapsamda parametrik olarak $\mathrm{t}$ testi, tek yönlü Anova testi ve Anova sonrası farklılık bulunan grupların kaynağını incelemede ise post-hoc analizlerine başvurulmuştur. Manidarlık 0,05 düzeyinde sınanmıştır.

\section{Bulgular}

Tablo 2' de katılımcıların tanımlayıcı özelliklerine yönelik veriler yer almaktadır.

Tablo 2. Katılımcıların Tanımlayıcı Özellikleri

\begin{tabular}{llcc}
\hline & Grup & Frekans (n) & Yüzde (\%) \\
\hline \multirow{2}{*}{ Yaş } & 35 yaş ve altı & 193 & 49,0 \\
Cinsiyetiniz & 36 yaş ve üzeri & 201 & 51,0 \\
\multirow{3}{*}{ Medeni Durumunuz } & Kadın & 152 & 38,6 \\
& Erkek & 242 & 61,4 \\
& Evli & 216 & 54,8 \\
Eğitim Durumunuz & Bekâr & 178 & 45,2 \\
& Lise ve altı & 76 & 19,3 \\
& Ön lisans & 90 & 22,8 \\
Online Bankacılığı Hangi Sıklıkta & Lisans & 184 & 46,7 \\
Kullanıyorsunuz & Lisansüstü & 44 & 11,2 \\
& Hergün & 176 & 44,7 \\
& Haftada bir kaç kez & 154 & 39,1 \\
Online Bankacılıkta En Çok & Ayda bir kaç kez & 20 & 5,1 \\
Yaptığınız İşlem Hangisidir & Ayda 1 & 30 & 7,6 \\
& Para transferi & 14 & 3,6 \\
& Ödemeler & 128 & 32,5 \\
& Kredi kartı işlemleri & 172 & 43,7 \\
& Diğer & 40 & 10,2 \\
& & 54 & 13,7 \\
\hline
\end{tabular}

Tablo 2' deki veriler incelendiğinde araştırmaya katılanların 193'ü (\% 49,0) 35 yaş ve altı, 201'i (\% 51,0) 36 yaş ve üzeri yaşlarda olup, 152'si (\%38,6) kadın, 242'si (\%61,4) erkek, 216's1 (\%54,8) evli, 178'i (\%45,2) bekârdır.Katılımcların 76'sı (\%19,3) lise ve altı, 90'nı (\%22,8) ön lisans, 184'ü $(\% 46,7)$, lisans, $44^{\prime} \ddot{u}(\% 11,2)$ lisansüstü mezunu olarak dağılmaktadır. 
Katılımcılar online bankacılık kullanma sıklığına göre 176'si $(\% 44,7)$ hergün, 154'"ü $(\% 39,1)$ haftada bir kaç kez, 20'si (\%5,1) haftada 1, 30'u (\%7,6) ayda bir kaç kez, 14'ü $(\% 3,6)$ ayda 1 olarak dağılmaktadır. Online bankacılıkta en çok yaptıkları işlemlere göre 128 'i $(\% 32,5)$ para transferi, 172'si $(\% 43,7)$ ödemeler, 40’1 $(\% 10,2)$ kredi kartı işlemleri, 54'ü $(\% 13,7)$ diğer olarak dağılmaktadır.

Araştırmaya katılanların online bankacılığa yönelik tutum ve davranışlarının ortalamaları Tablo 3'de verilmiştir

Tablo 3. Online Bankacılık Tutum ve Davranış Puanlarının Ortalaması

\begin{tabular}{lcccc}
\hline & N & Ort. & Ss. & Düzey \\
\hline Güven & 394 & 4,0295 &, 65604 & Yüksek \\
Sadakat/bağlılık & 394 & 3,9175 &, 68368 & Yüksek \\
Hizmet kalitesi & 394 & 3,9371 &, 74782 & Yüksek \\
Kullanım kolaylığı & 394 & 3,7635 &, 52798 & Yüksek \\
Algılanan fayda & 394 & 4,3194 &, 70371 & Çok Yüksek \\
Davranışsal niyet & 394 & 4,3299 &, 69368 & Çok Yüksek \\
Müşteri memnuniyeti & 394 & 4,0549 &, 60761 & Yüksek \\
\hline
\end{tabular}

Tablo 3'deki verilere bakıldığında; araştırmaya katılanların online bankacılığa yönelik tutum

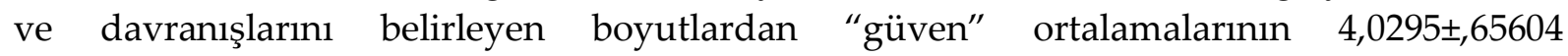

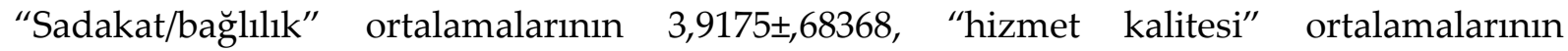

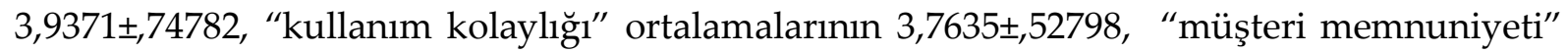

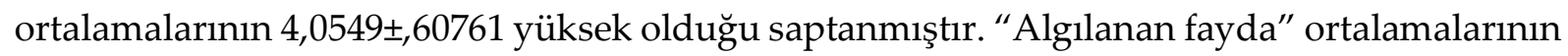

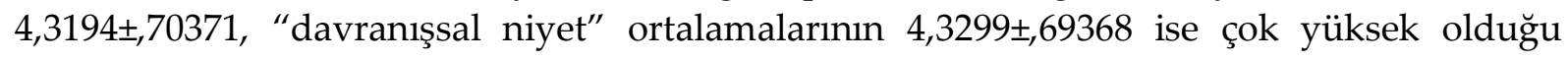
saptanmıştır.

Tablo 4. Online Bankacılık Tutum ve Davranış Puanlarının Yaşlarına Göre Farklılaşma

Durumu

\begin{tabular}{lllllccc}
\hline & Grup & N & Ort. & Ss. & t & sd & p \\
\hline \multirow{2}{*}{ Güven } & 35 yaş ve altı & 193 & 3,9666 &, 70206 & $-1,873$ & 392 &, 062 \\
& 36 yaş ve üzeri & 201 & 4,0900 &, 60419 & & & \\
Sadakat/bağlılık & 35 yaş ve altı & 193 & 3,8562 &, 68398 & $-1,748$ & 392 &, 081 \\
& 36 yaş ve üzeri & 201 & 3,9764 &, 67989 & & & \\
Hizmet kalitesi & 35 yaş ve altı & 193 & 3,8776 &, 79718 & $-1,550$ & 392 &, 122 \\
Kullanım & 36 yaş ve üzeri & 201 & 3,9943 &, 69435 & & & \\
kolaylığı & 35 yaş ve altı & 193 & 3,7192 &, 60699 & $-1,635$ & 392 & \multirow{2}{*}{, 103} \\
Algılanan fayda & 36 yaş ve üzeri & 201 & 3,8060 &, 43631 & & & \\
& 35 yaş ve altı & 193 & 4,2910 &, 77304 &,- 783 & 392 & \multirow{2}{*}{, 434} \\
Davranışsal niyet & 36 yaş ve üzeri & 201 & 4,3466 &, 63078 & & & \\
Müşteri & 35 yaş ve altı & 193 & 4,2448 &, 78311 & $-2,401$ & 392 &, 017 \\
memnuniyeti & 36 yaş ve üzeri & 201 & 4,4117 &, 58575 & & & \\
\hline
\end{tabular}


Tablo 4'deki verilere bakıldığında; katılımcıların yaşlarına göre davranışsal niyet puanları anlamlı farklılık göstermektedir $(\mathrm{t}(392)=-2,401 \mathrm{p}=0.041<0,05)$. Farklılığın nedenini belirlemeye yönelik yapılan post-hoc analizine göre; 36 yaş ve altı üzeri olanların davranışsal niyet puanları $(\bar{x}=4,4117), 35$ yaş ve altı olanlardan $(\bar{x}=4,2448)$ yüksek bulunmuştur.

Katılımcıların güven, sadakat/bağlılık, hizmet kalitesi, kullanım kolaylığı, algılanan fayda ve müşteri memnuniyeti puanları yaşlarına göre anlamlı farklılık göstermemektedir ( $>0,05)$.

Tablo 5. Online Bankacılık Tutum ve Davranış Puanlarının Cinsiyetlerine Göre Farklılaşma

Durumu

\begin{tabular}{|c|c|c|c|c|c|c|c|}
\hline & Grup & $\mathbf{N}$ & Ort. & Ss. & $\mathbf{t}$ & sd & $\mathrm{p}$ \\
\hline \multirow{2}{*}{ Güven } & Kadın & 152 & 4,0251 & ,53729 & \multirow{2}{*}{-,106 } & \multirow{2}{*}{392} & \multirow{2}{*}{,916 } \\
\hline & Erkek & 242 & 4,0323 & 72177 & & & \\
\hline \multirow{2}{*}{ Sadakat/bağlılık } & Kadın & 152 & 3,9474 & ,57445 & \multirow{2}{*}{687} & \multirow{2}{*}{392} & \multirow{2}{*}{ 493 } \\
\hline & Erkek & 242 & 3,8988 & 74468 & & & \\
\hline \multirow{2}{*}{ Hizmet kalitesi } & Kadın & 152 & 3,9514 & ,59266 & \multirow{2}{*}{,300 } & \multirow{2}{*}{392} & \multirow{2}{*}{,764 } \\
\hline & Erkek & 242 & 3,9282 & 83167 & & & \\
\hline \multirow{2}{*}{ Kullanım kolaylığı } & Kadın & 152 & 3,8171 & ,38236 & \multirow{2}{*}{1,602} & \multirow{2}{*}{392} & \multirow{2}{*}{ 110 } \\
\hline & Erkek & 242 & 3,7298 & 60002 & & & \\
\hline \multirow{2}{*}{ Algilanan fayda } & Kadın & 152 & 4,3300 & 61424 & \multirow{2}{*}{,238 } & \multirow{2}{*}{392} & \multirow{2}{*}{812} \\
\hline & Erkek & 242 & 4,3127 & 75567 & & & \\
\hline \multirow{2}{*}{ Davranışsal niyet } & Kadın & 152 & 4,4079 & ,57521 & \multirow{2}{*}{1,772} & \multirow{2}{*}{392} & \multirow{2}{*}{,077 } \\
\hline & Erkek & 242 & 4,2810 & 75573 & & & \\
\hline \multirow{2}{*}{ Müşteri memnuniyeti } & Kadın & 152 & 4,0491 & ,49572 & \multirow{2}{*}{,- 149} & \multirow{2}{*}{392} & \multirow{2}{*}{881} \\
\hline & Erkek & 242 & 4,0585 & 66936 & & & \\
\hline
\end{tabular}

Tablo 5'deki verilere bakıldığında; katılımcıların güven, sadakat/bağlılık, hizmet kalitesi, kullanım kolaylığı, algılanan fayda, davranışsal niyet ve müşteri memnuniyeti puanları cinsiyetlerine göre anlamlı farklılık göstermemektedir ( $p>0,05)$.

Tablo 6. Online Bankacılık Tutum ve Davranış Puanlarının Medeni Durumlarına Göre

Farklilaşma Durumu

\begin{tabular}{|c|c|c|c|c|c|c|c|}
\hline & Grup & $\mathbf{N}$ & Ort. & Ss. & $t$ & sd & $p$ \\
\hline \multirow{2}{*}{ Güven } & Evli & 216 & 4,0800 & ,58893 & \multirow{2}{*}{1,685} & \multirow{2}{*}{392} & \multirow{2}{*}{,093 } \\
\hline & Bekâr & 178 & 3,9683 & ,72626 & & & \\
\hline \multirow{2}{*}{ Sadakat/bağlılık } & Evli & 216 & 3,9653 & 67639 & \multirow{2}{*}{1,530} & \multirow{2}{*}{392} & \multirow{2}{*}{,127 } \\
\hline & Bekâr & 178 & 3,8596 & 68987 & & & \\
\hline \multirow{2}{*}{ Hizmet kalitesi } & Evli & 216 & 3,9865 & 67680 & \multirow{2}{*}{1,444} & \multirow{2}{*}{392} & \multirow{2}{*}{, 149 } \\
\hline & Bekâr & 178 & 3,8773 & ,82385 & & & \\
\hline \multirow{2}{*}{ Kullanım kolaylığı } & Evli & 216 & 3,8250 & ,40546 & \multirow{2}{*}{2,567} & \multirow{2}{*}{392} & \multirow{2}{*}{,011 } \\
\hline & Bekâr & 178 & 3,6888 & 63955 & & & \\
\hline \multirow{2}{*}{ Algılanan fayda } & Evli & 216 & 4,3071 & 66905 & \multirow{2}{*}{,- 381} & \multirow{2}{*}{392} & \multirow{2}{*}{,703 } \\
\hline & Bekâr & 178 & 4,3343 & 74525, & & & \\
\hline \multirow{2}{*}{ Davranışsal niyet } & Evli & 216 & 4,3472 & 64324 & \multirow{2}{*}{, 544} & \multirow{2}{*}{392} & \multirow{2}{*}{, 587} \\
\hline & Bekâr & 178 & 4,3090 & 75167 & & & \\
\hline \multirow{2}{*}{$\begin{array}{l}\text { Müşteri } \\
\text { memnuniyeti }\end{array}$} & Evli & 216 & 4,0986 & ,55494 & \multirow{2}{*}{1,579} & \multirow{2}{*}{392} & \multirow{2}{*}{ 115 } \\
\hline & Bekâr & 178 & 4,0017 & 66368 & & & \\
\hline
\end{tabular}


Tablo 6' daki verilere bakıldığında; katılımcıların medeni durumlarına göre kullanım kolaylığ

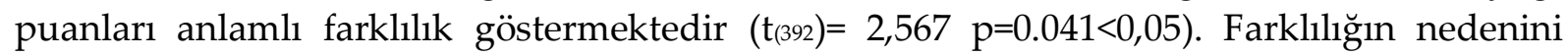
belirlemeye yönelik yapılan post-hoc analizine göre; evlilerin kullanım kolaylı̆̆ı puanları $(\bar{x}=3,8250)$, bekâr olanların puanlarından $(\bar{x}=3,6888)$ yüksek bulunmuştur.

Katılımcıların güven, sadakat/bağlılık, hizmet kalitesi, algılanan fayda, davranışsal niyet ve müşteri memnuniyeti puanları medeni durumlarına göre anlamlı farklılık göstermemektedir $(\mathrm{p}>0,05)$.

Tablo 7. Online Bankacılık Tutum ve Davranış Puanlarının Eğitim Durumlarına Göre

Farklılaşma Durumu

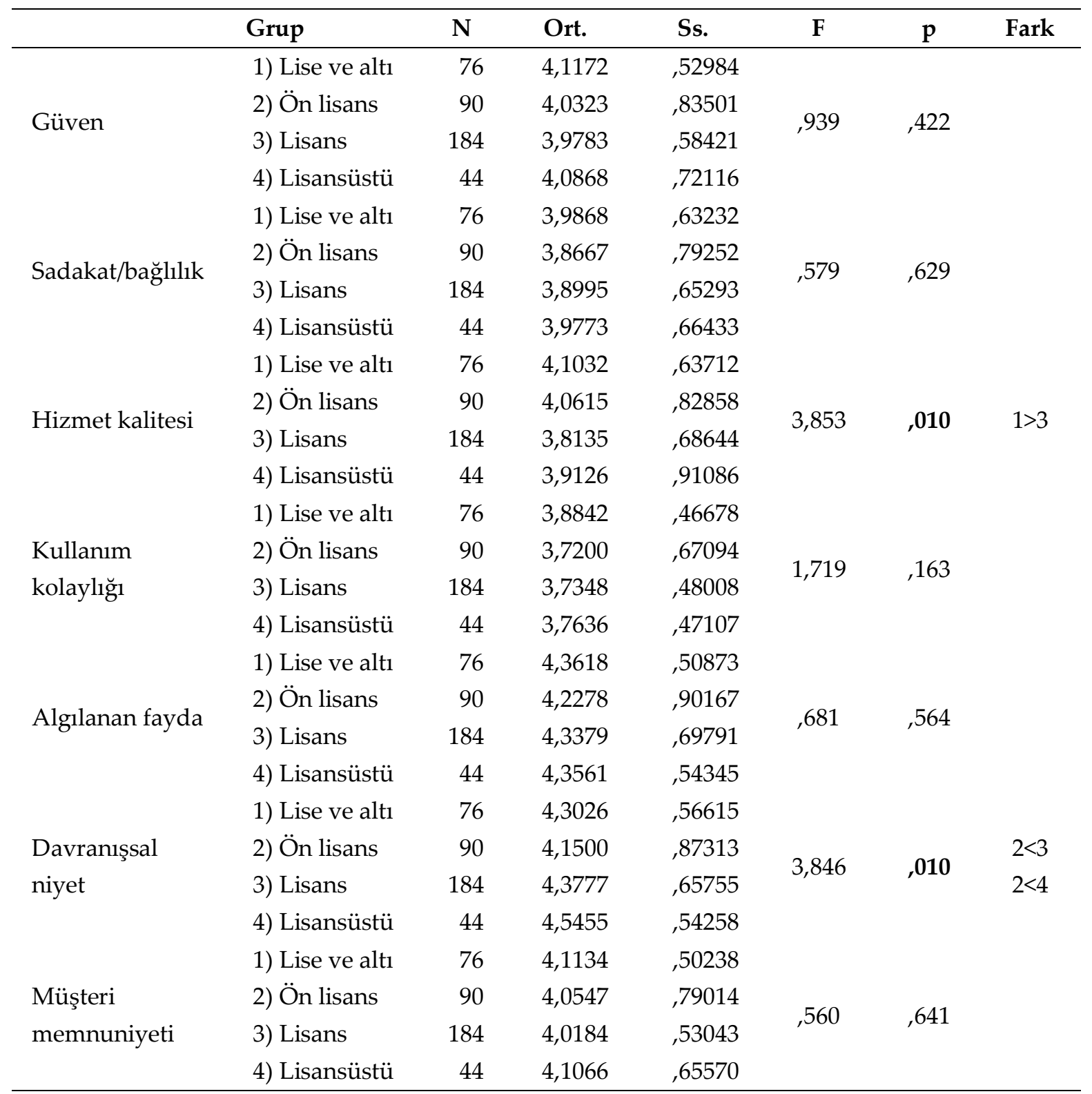

Tablo 7'deki verilere bakıldığında araştırmaya katılanların eğitim durumlarına göre hizmet kalitesi puanları anlamlı farklılık göstermektedir $(\mathrm{F}=3,853 ; \mathrm{p}=0,047<0.05)$. Farklılığın nedenini belirlemeye yönelik yapılan post-hoc analizine göre; eğitim durumu lise ve altı olanların 
hizmet kalitesi puanları $(\bar{x}=4,1032)$, eğitim durumu lisans olanlardan $(\bar{x}=3,8135)$ yüksek bulunmuştur.

Katılımcıların eğitim durumlarına göre davranışsal niyet puanları anlamlı farklılık göstermektedir $(\mathrm{F}=3,846 ; \mathrm{p}=0,003<0.05)$. Farklılı̆̆ın nedenini belirlemeye yönelik yapılan posthoc analizine göre; eğitim durumu ön lisans olanların davranışsal niyet puanları ( $\bar{x}=4,1500)$, eğitim durumu lisans $(\overline{\mathrm{x}}=4,3777)$ ve lisansüstü olanlardan $(\overline{\mathrm{x}}=4,5455)$ düşük bulunmuştur.

Katılımcıların güven, sadakat/bağlılık, kullanım kolaylığı algılanan fayda ve müşteri memnuniyeti puanları eğitim durumlarına göre anlamlı farklılık göstermemektedir( $p>0.05)$.

Tablo 8. Online Bankacılık Tutum ve Davranış Puanlarının Online Bankacılık Kullanma

Sıklığına Göre Farklılaşma Durumu

\begin{tabular}{|c|c|c|c|c|c|c|c|}
\hline & Grup & $\mathbf{N}$ & Ort. & Ss. & F & $\mathrm{p}$ & Fark \\
\hline \multirow[t]{5}{*}{ Güven } & 1)Hergün & 176 & 4,1353 & 70926 & \multirow{5}{*}{3,512} & \multirow{5}{*}{,008 } & \multirow{5}{*}{$1>4$} \\
\hline & 2)Haftada bir kaç kez & 154 & 3,9492 &, 56079 & & & \\
\hline & 3)Haftada 1 & 20 & 4,2091 & ,45320 & & & \\
\hline & 4)Ayda bir kaç kez & 30 & 3,7758 & 78230 & & & \\
\hline & 5) Ayda 1 & 14 & 3,8701 & 64747 & & & \\
\hline Sadakat/bağlı & 1)Hergün & 176 & 4,0568 & 72774 & \multirow{5}{*}{5,343} & \multirow{5}{*}{,000 } & \multirow{5}{*}{$\begin{array}{l}1>2 \\
1>4\end{array}$} \\
\hline \multirow[t]{4}{*}{ lik } & 2)Haftada bir kaç kez & 154 & 3,8214 & ,59113 & & & \\
\hline & 3)Haftada 1 & 20 & 4,1000 & 64072 & & & \\
\hline & 4)Ayda bir kaç kez & 30 & 3,6167 & 75923 & & & \\
\hline & 5) Ayda 1 & 14 & 3,6071 &, 51622 & & & \\
\hline Hizmet & 1)Hergün & 176 & 4,0280 & ,83143 & \multirow{5}{*}{3,250} & \multirow{5}{*}{,012 } & \multirow{5}{*}{$3>4$} \\
\hline \multirow[t]{4}{*}{ Kalitesi } & 2)Haftada bir kaç kez & 154 & 3,8501 & 65942 & & & \\
\hline & 3)Haftada 1 & 20 & 4,2692 & ,48554 & & & \\
\hline & 4)Ayda bir kaç kez & 30 & 3,6667 & 79822 & & & \\
\hline & 5) Ayda 1 & 14 & 3,8571 & ,41243 & & & \\
\hline Kullanim & 1)Hergün & 176 & 3,7409 & ,57304 & \multirow{5}{*}{1,388} & \multirow{5}{*}{ 237 } & \\
\hline \multirow[t]{4}{*}{ kolaylığ1 } & 2)Haftada bir kaç kez & 154 & 3,7662 & ,45550 & & & \\
\hline & 3)Haftada 1 & 20 & 4,0000 & ,00000 & & & \\
\hline & 4)Ayda bir kaç kez & 30 & 3,6800 & 76762 & & & \\
\hline & 5) Ayda 1 & 14 & 3,8571 & ,36314 & & & \\
\hline \multirow{5}{*}{$\begin{array}{l}\text { Algilanan } \\
\text { fayda }\end{array}$} & 1)Hergün & 176 & 4,4119 & ,76489 & \multirow{5}{*}{5,394} & \multirow{5}{*}{,000 } & \\
\hline & 2)Haftada bir kaç kez & 154 & 4,3279 &, 54780 & & & $1>4$ \\
\hline & 3)Haftada 1 & 20 & 4,4083 & 41702 & & & $1>5$ \\
\hline & 4)Ayda bir kaç kez & 30 & 3,8889 & 1,04435 & & & $2>4$ \\
\hline & 5) Ayda 1 & 14 & 3,8571 & 29855 & & & \\
\hline \multirow{5}{*}{$\begin{array}{l}\text { Davranışsal } \\
\text { niyet }\end{array}$} & 1)Hergün & 176 & 4,4006 & 74789 & \multirow{5}{*}{3,177} & \multirow{5}{*}{,014 } & \multirow{5}{*}{$1>4$} \\
\hline & 2)Haftada bir kaç kez & 154 & 4,3279 &, 56049 & & & \\
\hline & 3)Haftada 1 & 20 & 4,4500 & ,52315 & & & \\
\hline & 4)Ayda bir kaç kez & 30 & 3,9833 & ,98027 & & & \\
\hline & 5) Ayda 1 & 14 & 4,0357 & ,56208 & & & \\
\hline \multirow{5}{*}{$\begin{array}{l}\text { Müşteri } \\
\text { memnuniyeti }\end{array}$} & 1)Hergün & 176 & 4,1543 & 65367 & \multirow{5}{*}{3,865} & \multirow{5}{*}{,004 } & \multirow{5}{*}{$1>4$} \\
\hline & 2)Haftada bir kaç kez & 154 & 3,9850 &, 50874 & & & \\
\hline & 3)Haftada 1 & 20 & 4,2308 & ,44784 & & & \\
\hline & 4)Ayda bir kaç kez & 30 & 3,8000 & 74596 & & & \\
\hline & 5) Ayda 1 & 14 & 3,8681 & 63391 & & & \\
\hline
\end{tabular}


Tablo 8'deki verilere bakıldığında araştırmaya katılanların online bankacılık kullanma sıklığına göre güven puanları anlamlı farklılık göstermektedir $(F=3,512 ; p=0,047<0.05)$. Farklılı̆̆ın nedenini belirlemeye yönelik yapılan post-hoc analizine göre; hergün online bankacılık kullananların güven puanları $(\bar{x}=4,1353)$, ayda bir kaç kez kullananlardan $(\bar{x}=3,7758)$ yüksek bulunmuştur.

Katılımcıların online bankacılık kullanma sıklığına göre Sadakat/bağlılık puanları anlamlı farklılık göstermektedir $(\mathrm{F}=5,343 ; \mathrm{p}=0,047<0.05)$. Farklılı̆̆ın nedenini belirlemeye yönelik yapılan post-hoc analizine göre; hergün online bankacılık kullananların sadakat/bağlılık puanları $(\bar{x}=4,0568)$, haftada bir kaç $\operatorname{kez}(\bar{x}=3,8214)$ ve ayda bir kaç kez kullananlardan $(\bar{x}=3,6167))$ yüksek bulunmuştur.

Katılımcıların online bankacılık kullanma sıklığına göre hizmet kalitesi puanları anlamlı farklılık göstermektedir $(F=3,250 ; p=0,047<0.05)$. Farklılı̆̆ın nedenini belirlemeye yönelik yapılan post-hoc analizine göre; haftada 1 online bankacılık kullananların hizmet kalitesi puanları $(\bar{x}=4,2692)$ ayda bir kaç kez kullananlardan $(\bar{x}=3,6667)$ yüksek bulunmuştur.

Katılımcıların online bankacılık kullanma sıklı̆̆ına göre algılanan fayda puanları anlamlı farklılık göstermektedir $(\mathrm{F}=5,394 ; \mathrm{p}=0,047<0.05)$. Farklılı̆̆ın nedenini belirlemeye yönelik yapılan post-hoc analizine göre; hergün online bankacılık kullananların algılanan fayda puanların $(\bar{x}=4,4119)$ ayda bir kaç kez $(\bar{x}=3,8889)$ ve ayda 1 kullananlardan $(\bar{x}=3,8571)$ yüksek bulunmuştur. Haftada bir kaç kez online bankacıllk kullananların algılanan fayda puanların $(\bar{x}=4,3279)$ ayda bir kaç kez kullananlardan $(\bar{x}=3,8889)$ yüksek bulunmuştur.

Katılımcıların online bankacılık kullanma sıklığına göre davranışsal niyet puanları anlamlı farkl1lık göstermektedir ( $F=3,177 ; p=0,047<0.05)$. Farklılı̆̆ın nedenini belirlemeye yönelik yapılan post-hoc analizine göre; hergün online bankacılık kullananların davranışsal niyet puanları $(\overline{\mathrm{x}}=4,4006)$ ayda bir kaç kez kullananlardan $(\overline{\mathrm{x}}=3,9833)$ yüksek bulunmuştur.

Katılımcıların online bankacılık kullanma sıklığına göre müşteri memnuniyeti puanları anlamlı farklılık göstermektedir $(F=3,865 ; \mathrm{p}=0,047<0.05)$. Farklılı̆̆ın nedenini belirlemeye yönelik yapılan post-hoc analizine göre; hergün online bankacılık kullananların müşteri memnuniyeti puanları $(\bar{x}=4,1543)$ ayda bir kaç kez kullananlardan $(\bar{x}=3,8000)$ yüksek bulunmuştur

Katılımcıların kullanım kolaylığı puanları online bankacılık kullanma sıklığına göre anlamlı farkl1lık göstermemektedir ( $\mathrm{p}>0.05)$. 
Tablo 9. Online Bankacılık Tutum ve Davranış Puanlarının Online Bankacılıkta En Çok Yaptıkları İşleme Göre Farklılaşma Durumu

\begin{tabular}{|c|c|c|c|c|c|c|}
\hline & Grup & $\mathbf{N}$ & Ort. & Ss. & $\mathbf{F}$ & $\mathrm{p}$ \\
\hline \multirow{4}{*}{ Güven } & Para transferi & 128 & 4,0440 & 70768 & \multirow{4}{*}{1,801} & \multirow{4}{*}{146} \\
\hline & Ödemeler & 172 & 3,9556 & 62471 & & \\
\hline & Kredi kartı işlemleri & 40 & 4,1091 & ,76510 & & \\
\hline & Diğer & 54 & 4,1717 &, 50775 & & \\
\hline \multirow{4}{*}{ Sadakat/bağllık } & Para transferi & 128 & 3,9883 & 77920 & \multirow{4}{*}{2,444} & \multirow{4}{*}{,064 } \\
\hline & Ödemeler & 172 & 3,8140 & 64797 & & \\
\hline & Kredi kartı işlemleri & 40 & 3,9750 & ,59861 & & \\
\hline & Diğer & 54 & 4,0370 & ,57340 & & \\
\hline \multirow{4}{*}{ Hizmet kalitesi } & Para transferi & 128 & 3,9832 & ,83593 & \multirow{4}{*}{1,233} & \multirow{4}{*}{297} \\
\hline & Ödemeler & 172 & 3,8721 & 72195 & & \\
\hline & Kredi kartı işlemleri & 40 & 3,8885 & 79502 & & \\
\hline & Diğer & 54 & 4,0712 & ,53542 & & \\
\hline \multirow{4}{*}{$\begin{array}{l}\text { Kullanım } \\
\text { kolaylığı }\end{array}$} & Para transferi & 128 & 3,7719 &, 50617 & \multirow{4}{*}{1,951} & \multirow{4}{*}{, 12} \\
\hline & Ödemeler & 172 & 3,7279 & ,59739 & & \\
\hline & Kredi kartı işlemleri & 40 & 3,6900 &, 53002 & & \\
\hline & Diğer & 54 & 3,9111 & ,25378 & & \\
\hline \multirow{4}{*}{ Algilanan fayda } & Para transferi & 128 & 4,3607 & 77408 & \multirow{4}{*}{ 633 } & \multirow{4}{*}{, 59} \\
\hline & Ödemeler & 172 & 4,2742 & 71024 & & \\
\hline & Kredi kartı işlemleri & 40 & 4,2792 & 67028 & & \\
\hline & Diğer & 54 & 4,3951 & ,51017 & & \\
\hline \multirow{4}{*}{ Davranışsal niyet } & Para transferi & 128 & 4,4063 & 71472 & \multirow{4}{*}{1,311} & \multirow{4}{*}{,271 } \\
\hline & Ödemeler & 172 & 4,2558 & ,75217 & & \\
\hline & Kredi kartı işlemleri & 40 & 4,4000 &, 56840 & & \\
\hline & Diğer & 54 & 4,3333 & ,49526 & & \\
\hline \multirow{4}{*}{$\begin{array}{l}\text { Müşteri } \\
\text { memnuniyeti }\end{array}$} & Para transferi & 128 & 4,0727 & 66791 & \multirow{4}{*}{2,170} & \multirow{4}{*}{, 091} \\
\hline & Ödemeler & 172 & 3,9785 & ,57632 & & \\
\hline & Kredi kartı işlemleri & 40 & 4,1346 & 67953 & & \\
\hline & Diğger & 54 & 4,1966 & 46073 & & \\
\hline
\end{tabular}

Tablo 9'daki verilere bakıldığında; katılımcıların güven, sadakat/bağlılık, hizmet kalitesi, kullanım kolaylığı, algılanan fayda, davranışsal niyet ve müşteri memnuniyeti puanları online bankacılıkta en çok yaptıkları işleme göre anlamlı farklılık göstermemektedir $(p>0,05)$. 


\section{Tartışma, Sonuç ve Öneriler}

Online bankacılığa yönelik bireysel banka müşterilerinin tutum ve davranışlarını incelemek amacıyla gerçekleştirilen araştırmaya Niğde ilindeki 394 bireysel banka müşterisi katılmıştır.

193'ünün 35 yaş ve altında 201'inin 36 yaş ve üzerinde bulunan katılımcıların 242'si evli, 152'si bekardır. Yarısına yakınının (\%46,7) lisans mezunlarının oluşturduğu katılımcıların \%44,7'si online bankacılığı her gün, \%39,1'iise haftada birkaç kez online bankacılığı kullanmaktadır. Online bankacılık işlemleri arasında en fazla \%43,7oranında ödeme işlemleri ve \%32,5 oranında para transferi işlemleri gerçekleştirilmektedir.

Araştırmada katılımcıların online bankacılığa yönelik tutum ve davranışları güven, sadakat, hizmet kalitesi, kullanım kolaylığı, algılanan fayda, davranışsal niyet ve müşteri memnuniyetleri boyutlarında incelenmiş ve 5 üzerinden değerlendirilmiştir. Buna göre katılımcıların en olumlu tutum ve davranışlarının 4,3299 ortalama ile davranışsal niyet boyutuna yönelik olduğu, en düşük tutum ve davranışlarının ise 3,7635 ortalama ile kullanım kolaylığı boyutuna ait olduğu belirlenmiştir. Buradan bireysel banka müşterilerinin online bankacilığa yönelik davranışsal niyetlerinin daha olumlu olduğu ve diğer boyutlara göre online bankacılığın kullanım kolaylığına ilişkin algılarının daha düşük olduğu saptanmıştır.

Araştırmada bireysel bankacılık müşterilerinin tanımlayıcı özelliklerine göre online bankacılığa yönelik tutum ve davranışlarında farklılık olup olmadığ 1 da sorgulanmıştır. Bu doğrultuda ele alınan ilk değişken olarak katılımcıların yaşlarına göre davranışsal niyet boyutu dışındaki online bankacılığa yönelik tutum ve davranış boyutlarında farklılıkların olmadığı belirlenmiştir. Buradan 36 yaş ve üzerindeki banka müşterilerinin davranışsal niyet düzeyleri 35 yaş ve altındaki katılımcılardan yüksek olduğu, diğer online bankacılığa yönelik tutum ve davranışlarını belirleyen boyutlara ilişkin algılarının ise benzer düzeyde olduğu sonucuna ulaşılmıştır. Vural'ın (2019) 10 boyutlu farklı bir ölçek kullanarak yaptığ araştırmasında da bu araştırmada olduğu gibi tek boyut dışında katılımcıların yaşlarına göre online bankacılığa yönelik tutum ve davranışlarında farklılıkların olmadığı belirlenmiştir. Bu yönüyle araştırma sonuçları birbirini desteklemektedir.

Araştırmaya katılan bireysel banka müşterilerinin cinsiyetlerine göre online bankacılığa yönelik tutum ve davranışlarında istatistiksel olarak farklılaşma olmadığı belirlenmiştir. Diğer bir ifadeyle kadın ve erkek bireysel banka müşterilerinin online bankacılığa yönelik tutum ve davranışları benzer düzeydedir. Literatürde yapılan araştırmalarda da online bankacılığa yönelik tutum ve davranışlarda cinsiyetin bağımsız olduğu sonucuna ulaşılmaktadır (Kaplan, 2020; Vural, 2019; Özkan ve İpekten, 2017).

Katılımcıların medeni durumlarına göre online bankacılığa yönelik tutum ve davranışlarını belirleyen boyutlardan kullanım kolaylığı dışında farklılık göstermemektedir. Buna göre evli katılımcıların bekar katılımcılara göre online bankacılığa yönelik tutum ve davranışları belirleyen boyutlardan kullanım kolaylığına ilişkin algıları daha olumlu iken diğer boyutlara ilişkin algıları birbirlerine benzerlik göstermektedir. Özkan ve İpekten (2017) araştırmalarında medeni durum ile online bankacilık kullanma durumu arasında anlamlı ilişki olmadığını saptamışlardır.

Katılımcıların eğitim durumlarına göre online bankacılığa yönelik tutum ve davranışlarını belirleyen boyutlardan hizmet kalitesi ve davranışsal niyet düzeylerinde farklılıklar saptanırken, güven, sadakat/bağlılık, kullanım kolaylığı ve müşteri memnuniyeti düzeylerinde farklılıkların olmadığı belirlenmiştir. Buna göre lise ve altı eğitim 
düzeyindekilerin lisans mezunlarına göre hizmet kalitesi algıları daha olumlu, önlisans mezunlarının da lisans ve lisansüstü eğitim durumundakilere göre davranışsal niyet algıları daha olumsuzdur. Literatürde öğrenim durumuna göre online bankacılığa yönelik tutum ve davranışlarda farklılaşma olmadığı yönünde sonuçlara ulaşıldığı gibi (Vural, 2019) öğrenim durumuna göre online bankacılığa yönelik tutum ve davranışlarda farklılaşmaların olduğu yönünde araştırma bulgularına da rastlanılmaktadır (Özkan ve İpekten, 2017; Kaplan, 2020). Araştırma sonuçlarının farklılaşma nedenlerinin örneklem grubundaki bulunan bireylerin eğitim durumlarına göre dağılımlarından kaynaklandığ 1 düşünülmektedir. Bu araştırmada katılımcıların yarısına yakını lisans $(\% 46,7)$ eğitim durumundadır.

Katılımcıların online bankacılığı kullanma sıklıklarına göre kullanım kolaylığı dışındaki online bankacılığa yönelik tutum ve davranışlarını belirleyen boyutlarda farklılaşma olmadığı saptanmıştır. Buna göre her gün online bankacılığg kullananların ayda birkaç kez kullananlara göre güven, sadakat/bağlılık, algılanan fayda, davranışsal niyet ve müşteri memnuniyetleri daha olumlu iken haftada 1 kullananların ayda birkaç kez kullananlara göre hizmet kalitesi algıları daha olumludur. Mantıksal açıdan bakıldığında da daha sık kullananların daha az kullananlara göre tutum ve davranışlarının daha olumlu olması olağan bir durumdur. Nitekim konu ile ilgili yapılan araştırmalara bakıldığında da kullanım sıklığının online bankacilığa yönelik tutum ve davranışlarda etkili olduğu görülmektedir (Kaplan, 2020; Vural, 2019).

Araştırmada katılımcıların online bankacılıkta en çok yaptıkları işlemlere göre online bankacılığa yönelik tutum ve davranışlarda farklılık olmadığı saptanmıştır. Başka bir ifade ile online bankacılıkta en fazla yaptıkları işlemler farklılaşan katılımcıların online bankacılığa yönelik tutum ve davranışları benzerlik göstermektedir.

Sonuç olarak bireysel banka müşterileri online bankacılığa yönelik oldukça olumlu tutumlar içerisindedirler. Çıkan bu sonuçta içinde bulunulan dönemdeki Covid-19 salgınının önemli etkisinin olduğu düşünülmektedir. Bankacılıkta en çok yapılan işlemin ve cinsiyetin online bankacılığa yönelik tutum ve davranıştan bağımsız olması, kadın ve erkek, her tür bankacılık işlemi için online bankacılığın önemli olduğunun göstergesidir. Diğer taraftan araştırmada; yaş, medeni durum, öğrenim durumu ve online bankacılık kullanım sıklığı, online bankacılığa yönelik tutum ve davranışlarda farklılaşmaya neden olan değişkenler olduğu saptanmıştır. Banka yetkililerinin bu sonuçları dikkate alarak online bankacılık hizmetlerini geliştirmelerinin müşteri memnuniyetlerine olumlu yansımalarının olacağ 1 düşünülmektedir. $\mathrm{Bu}$ araştırmanın sonuçları Niğde ilindeki 394 bireysel banka müşterisinin görüşleri ile sınırlıdır. Daha genel verilere ulaşmak için daha geniş örneklemler üzerinde araştırmalar yapılabileceği gibi farklı illerde veya kurumsal banka müşterileri, üniversite öğrencileri gibi farklı örneklemler üzerinde de araştırmalar gerçekleştirilebilir. 


\section{Kaynakça}

Abrol, S. (2014). Impact of internet banking on customer satisfaction and business performance (Thesis Submitted To The University of Jammu for The Award of The Degree of Doctor of Philosophy In Commerce).

Alsajjan, B., \& Dennis, C. (2010). Internet banking acceptance model: Cross-market examination. Journal of Business Research, 63 (9), 957-963. https://doi.org/10.1016/j.jbusres.2008.12.014

Altunöz, U. (2016). Banka müşterilerinin internet bankacılığına yönelik davranışlarının incelenmesi: kümeleme analizi. Route Educational and Social Science Journal, 3(4), 132-141. http://www.ressjournal.com/Makaleler/938286560 9\%20Utku\%20altun\%c3\%b6z.pdf

Al-Weshah, G. A. (2013). The role of internet banking in continuous improvement areas: quantitative evidence from Jordanian banks. Int. J. of Business Performance Management, 14 (2), 181- 196. DOI: 10.1504 / IJBPM.2013.052950

Bankacılık Düzenleme ve Denetleme Kurumu (2020). Bankalarin bilgi sistemleri ve elektronik bankacilik hizmetleri hakkinda yönetmelik. Resmi Gazete. Sayı: 31069

Barışık, S., \& Temel, H. (2007). İnternet bankacılığı kullanımında güvenlik unsurlarının bilinirliği anket uygulamasına dayalı spss çözümlemesi. Zonguldak Karaelmas Üniversitesi İktisadi ve İdari Bilimler Fakültesi Dergisi, 2007 (2), 136-160. Retrieved from https://dergipark.org.tr/tr/pub/kmusekad/issue/10223/125679

Büyüköztürk, S., Çakmak, E., Akgün, Ö. E., Karadeniz, S., \& Demirel, F. (2016). Bilimsel araştırma yöntemleri (21. baskı). Ankara: Pegem Akademi Yayıncılık.

Doğan, M., Şen, R., \&Yilmaz, V. (2015). İnternet bankacılığına ilişkin davranışların planlanmış davranış teorisi ve teknoloji kabul modeli kullanılarak önerilen bir yapısal eşitlik modeliyle incelenmesi. Uşak Üniversitesi Sosyal Bilimler Dergisi, 8 (2), 1-22. Retrieved from https://dergipark.org.tr/tr/download/article-file/202542

https://www.nufusu.com/ilceleri/nigde-ilceleri-nufusu

Kaplan, E. (2019). Üniversite öğrencilerinin online bankacılık ile ilgili tutum ve davranışların incelenmesi: Niğde Ömer Halisdemir Üniversitesi öğrencileri üzerinde bir araştırma. Germir H. N (Ed.) Al Farabi 6th International Conference on Social Sciences, November 15-17, Adana- Turkey, ss.125-139. ISBN- 978-625-7029-45-2

Karasar, N. (2012). Bilimsel araştırma yöntemleri (24. bask1). Ankara: Nobel Yayınevi

Kaya, F., \& Arslan, T.R. (2016). İnternet bankacılığında müşterilerin banka tercihlerine etki eden faktörler: Bolu ilinde kamu çalışanları üzerine bir araştırma. Finansal Araştırmalar ve Çalışmalar Dergisi, 8 (15), 423-449. DOI: 10.14784/marufacd.266474

Kocabıyık, T., \& Fattah, A.Ş.F. (2019). Y kuşağının elektronik bankacılık ile ilgili tutum ve davranışları: Süleyman Demirel üniversitesi öğrencileri üzerine bir araştırma. Çoban, O., Ağcakaya, S., Karakoç, E., Karasioğlu, F., \& Çoban, A. (Ed.) Sosyal, beşeri ve idari bilimler alaninda araştırma ve değerlendirmeler Cilt 3, Ankara: Gece Akademi, 311-330

Lin, W. R., Wang, Y. H., \& Hung, Y. M. (2020). Analyzing the factors influencing adoption intention of internet banking: Applying DEMATEL-ANP-SEM approach. PloS One, 15(2), e0227852. https://doi.org/10.1371/journal.pone.0227852 
Okumuş, A., Bozbay, Z., \& Dağlı, R. M. (2010). Banka müşterilerinin internet bankacılığına ilişkin tutumlarının incelenmesi. Erciyes Üniversitesi İktisadi ve İdari Bilimler Fakültesi Dergisi, (36), 89-111. Retrieved from https://dergipark.org.tr/tr/download/article-file/66631

Özkan, T., \& İpekten, O.B. (2017). İnternet bankacılı̆̆1 kullanımını etkileyen faktörler: Atatürk Üniversitesi personeli üzerine bir uygulama. Atatürk Üniversitesi Sosyal Bilimler Enstitüsü Dergisi, 21(2), 647-664. Retrieved from https://dergipark.org.tr/tr/download/articlefile/474653

Pikkarainen, T., Pikkarainen, K., Karjaluoto, H., \& Pahnila, S. (2004). Consumer acceptance of online banking: an extension of the technology acceptance model. Internet Research, 14 (3), 224-235. https://doi.org/10.1108/10662240410542652

Solanki, U. (2018). Impact of electronic banking on customer satisfaction. International Journal of Trend in Scientific Research and Development (IJTSRD), 2 (5), 978-982. Retrieved from https://www.ijtsrd.com/papers/ijtsrd17012.pdf

Suriya, M., Mahalakshmi, V., \& Karthik, R., (2012). A study on customer perception towards internet banking. International Journal of Sales $\mathcal{E}$ Marketing Management Research and Development (IJSMMRD), 2 (3), 15-34. http://www.tjprc.org

Titu, M.A.S., \& Rahman, M.A. (2013). Online banking system-its application in some selected private commercial banks in Bangladesh. IOSR Journal of Business and Management (IOSR-

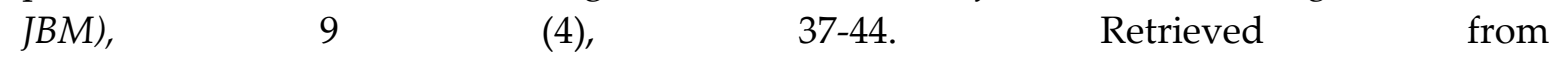
https://pdfs.semanticscholar.org/784f/cfa8544b38a1053e7b416ffc70cb69a88909.pdf

Uzundağ, Ş. (2013). Türkiye'de internet bankacıliğının gelişimi ve internet bankacılığına ilişkin tüketici davranışları analizi (Yayımlanmamış yüksek lisans tezi, Adnan Menderes Üniversitesi Sosyal Bilimler Enstitüsü, Aydın), Erişim adresi: https://tez.yok.gov.tr

Vatan Gazetesi (25 Eylül 2019). Hesaptan çalınan paradan banka sorumlu. http://www.gazetevatan.com/-hesaptan-calinan-paradan-banka-sorumlu--1276766ekonomi/

Vural, E. (2019). Bankacılık sektöründe internet bankacıliğg ve mobil bankacılık uygulamalarının finansal hizmet kalitesinin müşterileri tarafindan değerlendirilmesi: Bankacılıkta bir uygulama (Yüksek lisans tezi, Sivas Cumhuriyet Üniversitesi Sosyal Bilimler Enstitüsü, Sivas), Erişim adresi: https://tez.yok.gov.tr

Yılmaz, Ö., Boz, H., \& Yaprak, B. (2017). Tüketicinin bireysel banka tercihlerini etkileyen faktörlerin belirlenmesine yönelik bir uygulama: Balıkesir örneği. Uluslararası Sosyal Araştırmalar Kongresi (USAK'17), 20 - 22 Nisan, İstanbul, ss.1702-1709.I SBN: 978-605-82729$0-3$. 